(C) Economic Literature, Vol. XII (26-38), December 2014

\title{
Out of Place: Abandoned Children in Predicaments amid Alterations
}

\author{
Prakash Upadhyay, PhD*
}

\begin{abstract}
The major argument of this article is that amid the rhetoric of inclusion of castelethnic/regional groups in the national mainstream, street children known as vagrant kids are the victims of exclusion. In a new situation on the streets, Vagrant kids are the vagabond. However, abandoning the home and adjusting to the streets is a multifarious process. The forming of the vagrant kids is a complex itinerary actions embedded with the age, sex, and ethnicities/caste, place of origin, family economy, family roles and responsibilities. Among the multiple factors, family dysfunctions and company with street boys are the raison d'être for the emergence of street children culture. In a transformed situation on street, kids' lives have a momentous relationship to the street as a space and a new sub-culture in a new situation. In a rupture from works, which considers vagrant kids a hindrance to progressive social change, this study squabble that forming of vagrant kids is society ingrained and hence endorses role of community in bringing transference, meaningful development in the status of vagrant kids through an affirmative change in the behavior of the people and the government.
\end{abstract}

Keywords: vagrant, apathetic, sniffing, mugging, ravenous, intangible, solvents, sagacity, raucous.

\section{BACKGROUND}

Vagrant kids are the street children who live in garbage boxes, parks or on the road itself. Primary difficulty with vagrant kids is that there are no precise categories, but rather a gamut, ranging from children who fritter sometime in the streets and sleep in a house with ill-prepared adults, to those who live wholly in the streets and have no adult supervision or care. They are typically and deprecatingly called as Khate which is an exceedingly negative term and children refuse to be called that way. Nonetheless this word well describes the negative attitude towards vagrant kids. They are considered as social parasites, small criminals, drug abusers, and thieves. Their grimy and tattered clothes and refusal of any social constrains makes the general public think that vagrant kids are basically an unusual persons (CPCS 2009). As a diverse group the connotation of the term vagrant kids is widely debated. However, at the hub of each definition are children who are out of place. If they are sleeping, on the streets, they have lost or left their families and homes. If they spend their days working on the streets they have abandoned, or been abandoned by, the system of education. If they are playing in the streets, this is most likely because they lack other options. It is a veracity that children tend to be discriminated against in the statistical record

* Dr Upadhaya is Associate Professor of Anthropology at P.N. Campus, T. U. Pokhara. 
because the unit of observation tends to be adult-focused (such as households) or service-focused (such as clinics and schools). Yet children-centered statistics can usually be without problems calculated and are more useful for targeting programs at child protection and child poverty alleviation (ADB 2003).

With the brisk growth of urban centers, the number of vagrant kids is escalating in Nepal. The exact and reliable data on vagrant kids in Nepal is lacking as no provision has been made, so far, to enumerate these children in the national censuses. Although, the available data on vagrant kids, as reported by different organizations that are working in this sector, varies, it is roughly estimated that 'there are more than 5,000 such children living in the streets in Nepal' (CWIN, 2008). These children are scattered in various urban centers, mainly Kathmandu, Pokhara, and other urban and sub-urban centers. Nevertheless, they can be defined in various categories according to the time they spend on the streets, the work they do for their living and their personal and family background. A widely accepted set of definitions, commonly attributed to Amnesty International, divides vagrant kids into two main categories: Children of the street (of the street children) and Children on the street.

Children of the street or of the street children are those children who actually live on the street (or outside of a normal family environment). Family ties may exist but are tenuous and are maintained only casually or occasionally (Wikipedia 2010). This current study is based on the study of the street vagrant kids who actually live on street. On the other hand Children on the street are those children who are engaged in some kind of economic activity ranging from begging to vend. The majority goes home at the end of the day and contributes their earnings to their family. They may be attending school and retain a sense of belonging to a family. Because of the economic fragility of the family, these children may eventually opt for a permanent life on the streets.

Amid transformation in urban centers the uniqueness of children of the street is that they are the excluded proto-proletarians of the society retaining rudimentary features of bucolic culture and maintaining ties with bucolic origins despite their forming and transforming identity in the urban centers. These ill-fated street dwellers have been constantly been excluded from mainstream society--socially and economically and has been regarded problem creators for the society. Vagabond life, no fixed home, constrained access to resources, lack of education, opportunities, disempowerment, discrimination and marginalization, disregard for child rights, and capacity constraints are some of the key forms of segregation that vagrant kids are facing in urban centers. Social, economic and apathetic attitude of both -vagrant kids as well as the people continues to be a major hindrance. The major objective of this research was to explore the alterations 'of the street' vagrant kids in Pokhara in stipulations of their access to lifestyle and pecuniary strategies of income sources and predicaments.

\section{DATA AND METHODS}

The field work for data collection was accomplished from October 1 to 15, 2013. The study site was within the Pokhara sub-metropolitan city of Kaski district where the vagrant kids were making street as their dwelling in the different locations of the city-Mahendrapul, Chipledhunga, Prithvi Chowk, Amar Singh Chowk, Buddha Chowk, Bus park, New Road, Lakeside etc. 
According to a survey (unpublished report by CWSUK 2011) there are around 262 of the vagrant kids working and living in the street in Pokhara. It means 262 vagrant kids are permanently spending their lives in different streets location in Pokhara. In this study, the population to be studied has been identified and a sampling frame developed. Out of these, only 100 of the street vagrant kids have been taken for the study on the basis of purposive sampling method.

To meet the objectives of the study, the required data and information have been gathered through primary data collection techniques. The primary data have been acquired by face-to-face interviews of the street vagrant children with the help of an interview schedule. A similar type of interview was conducted with the diverse personalities of different organizations working in the sector of vagrant kids in order to obtain both qualitative and quantitative data for study. Vagrant kids were observed to record their behavioral patterns, objects and events in their daily lives. Participant Observation included, establishing rapport with the kids, and direct collection of primary data was made from the field. Personal observations were made with certain behavior of kids, such as kids picking rags under dangerous situations, sniffing glue, quarreling, begging, settling disputes etc.

Four sessions of FGD ( 5 kids in each group) was conducted in different centers of Pokhara where $20 \%$ of the total vagrant kids were interviewed. It enabled to collect ample data required for the exposition of authenticities related to vagrant kids. Help of facilitators (who were also the vagrant kids) were taken.

\section{RESULTS AND DISCUSSION}

\subsection{Profile of Vagrant Kids}

The growing number of slum areas around the hinterland of urban centers which itself lack settlements infrastructure, is an issue of great concern. It is giving rise to different tribulations and vagrant kids issue is embedded with the slum areas of urban centers to a great extent. Historically the concept of urbanization has been related to specialization, industrialization, and consequent economic development (Sharma, 2003). The characteristics of rapid urbanization are denoted by widespread urban poverty and the enormous number of urban dwellers suffering from a severe lack of basic services. Similarly, one of the basic urban services with signs of shortage is that of shelter, like the street dwellers of big cities, Shanties, all at least to the acute shortage of housing for the inhabitants (Yeung 1988). In the Nepalese context widespread urban poverty is veracity (Upadhyay, 2008). Huge number of urban dwellers suffering from a severe lack of basic services and problems in urban context are veracities and it is on these veracities that the plight and fate of vagrant kids is based. Despite the romanticism attached to Pokhara and its charms, Pokhara as an emerging city, is encountering tribulations with regards to vagrant kids who are scattered in different parts of the city, wherever it is convenient for them to collect rags and sell to the Kawadis (Junkers). The figure below illustrates the location of vagrant kids in Pokhara.

Kids abandon the home, approach to the streets, transform to a new circumstances, make their own identity and fiddle with to a new circumstances moderately dissimilar from their past. They hang 
around in different parts of Pokhara--Chipledhunga, Prithvichowk, Amarsing chowk, Bus Park areas etc. In new circumstances on the streets, Vagrant kids are the wanderers with no fixed location. Usually they stay in a group in or around junkyard (Gaddi, a place where they sell Kabadi they collect). The vagrant kids wander away in search of rags when they get rags; they sell the rags to the Kabadis. They make their living by selling the collected rags to the Kabadis. However, abandoning the home and adjusting to the streets is a complex process. The forming of the vagrant kids is an intricate process embedded with the age, sex, ethnicities/caste, place of origin, family economy.

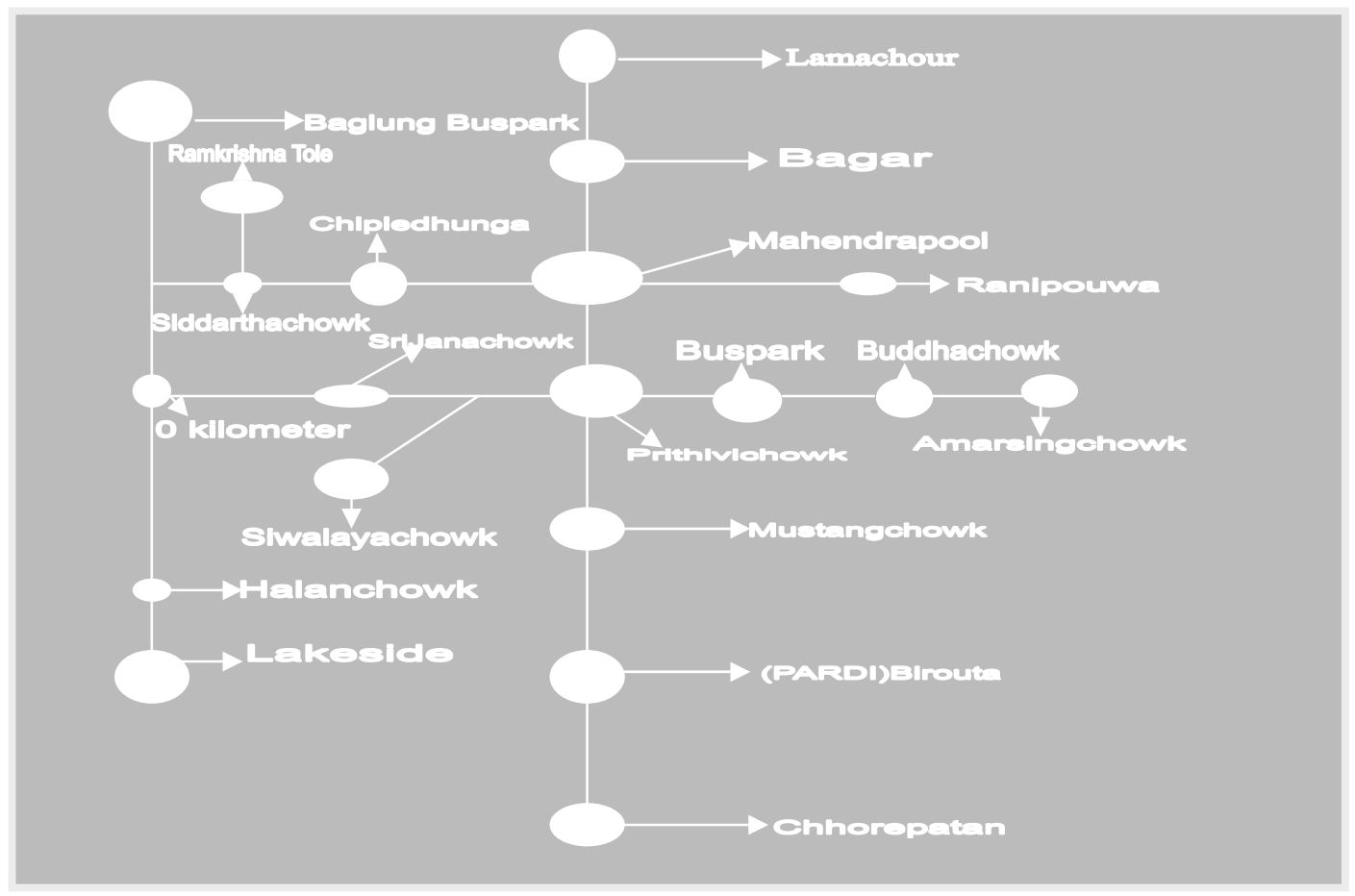

Figure 1: Vagrant kids Location in Pokhara

\section{Age, and Sex}

Altogether 100 children were studied. Among them there were two girls living on the street. Girls hardly spent their nights on the street as the boys did though they came to the street to pick rags and to do other activities during day time. Girls were easily victimized and assaulted on the street hence vagrant girls were seen occasionally on the street. 
Table 1: Vagrant Kids by Age Group

\begin{tabular}{lllllll}
\hline Age group & \multicolumn{2}{c}{ Male } & \multicolumn{2}{c}{ Female } & \multicolumn{2}{c}{ Total } \\
\cline { 2 - 5 } & No & Percentage & No & Percentage & No & Percentage \\
$9-12$ & 30 & 30 & 0 & 0.0 & 30 & 30 \\
$13-15$ & 50 & 50 & 0 & 0.0 & 50 & 50 \\
$16-18$ & 18 & 18 & 2 & 2 & 20 & 20 \\
Total & 98 & 98 & 2 & 2.0 & 100 & 100 \\
\hline
\end{tabular}

Source: Field Survey, 2013.

Of the 100 kids majority of the children's age group was $13-15$ followed by $9-12$. The percentage was 50 and 30 respectively and children between 16 to 18 year's ages were $20 \%$ only. It is because of the fact that 13-15 age group boys were most vulnerable to migrate to the city area. Besides, these age group children were mostly demanded in the city area to work in the household and hotel works.

\section{Caste/Ethnicity}

Caste is a closed social stratum based on heredity that determines its members' prestige, occupation, residence, and social relationships. Caste discrepancies are intimately linked to the Hindu caste system that divides the population into dozens of hereditary groups. Kids are from diverse groups.

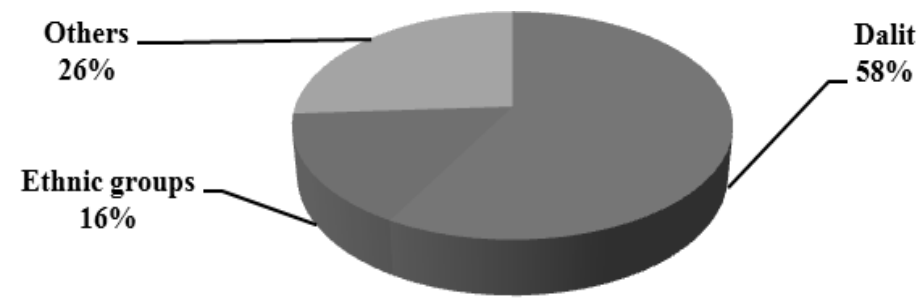

Figure 2: Vagrant Kids by Caste/Ethnicity

Fundamentally children come to the street from the community in and around the city and from adjoining districts. Mostly dalit children who are economically and socially underprivileged are high in number. Above all, Dalits kids' population is high on the street. Chhetri and Brahmin kids are also very few in number. Though Gurung population is dominant in the region, their children's number on the street is not so high. It is most probably because of good economic condition in this community mainly due to foreign employment and military profession in foreign countries. 


\section{Place of Origin}

Mostly the surveyed children were from western region. Kaski district contributed majority of the children. There are over 53 slum areas and urban poor settlements within the Pokhara valley (UNICEF 2010). These settlements have contributed not only labours to the city but also the children on the street. Such settlements are full of social crisis and problems because of ignorance, poverty, unemployment, illiteracy and family break-up. Being within the city or in vicinity, makes children more exposed to the street. Some kids are from faraway districts also.

Vagrant kids are from 14 districts and 26 percent of the Vagrant kids were from Kaski. This figure denotes that children living in the vicinity of urban centers have high chances of escaping to city centers but the far away kids are also pushed to the urban centers.

Table 2: District of Origin of Vagrant Kids

\begin{tabular}{lcc}
\hline \multicolumn{1}{c}{ Name of Districts } & Number & Percentage \\
\hline Baglung & 4 & 4.0 \\
Banke & 2 & 2.0 \\
Birgunj & 2 & 2.0 \\
Chitwan & 4 & 4.0 \\
Dadheldhura & 2 & 2.0 \\
Dhading & 12 & 12.0 \\
Gorkha & 6 & 6.0 \\
Kaski & 26 & 26.0 \\
Lamjung & 6 & 6.0 \\
Myagdi & 2 & 2.0 \\
Parbat & 8 & 8.0 \\
Rupandehi & 6 & 6.0 \\
Syangja & 12 & 12.0 \\
Tanahun & 8 & 8.0 \\
Total & 100 & 100.0 \\
\hline
\end{tabular}

Source: Field Survey, 2013

\section{Duration of Vagrant kids on the Street}

$11 \%$ of kids (both boys and girls) reported spending time on the street only within the last $0-6$ months compared to $41 \%$ kids reporting having spent 1-2 years on the street. This suggests an increase in the number of kids coming to work on the street. $34 \%$ kids reported of living on the street for 2-3 years. Only 5\% kids have been living on the street for the last 3-4 years compared to $4 \%$ kids claiming having spent 4-7 years on street. Kids living on the street for the last 7 years are only 2. This suggests that living on street for a long time is a difficult task. As the kids grow older and matured they choose alternative jobs and discard the streets. 


\subsection{Relationship with Community}

After arriving on the street, kids spent a major portion of their time in different ways. The vagrant kids spent a major portion of their time in junkyards called Kawaad. The Kawaads are a very important place and environment away from the street, able to entrée rag picking children at the time of work or when kids are not working. Vagrant kids involved in all varieties of rag picking job have strong relations with the Kawaads and local community or their work colleagues/companion. The scrap centers and local communities play an important role in the lives of many street-based children. This role can be both encouraging and unconstructive. This study revealed that some kawaads play an affirmative role in the children's lives providing knowledge's related to infectious diseases, preventing abuse of younger boys, regulating their drug use, encouraging them to save money, and supporting them to find other occupation. Vagrant kids often bring in the majority of their scrap and some kawaads have an impulse to keep children dependent on them. High risk activities are regularized in the day to day lives of the vagrant kids.

A diverse range of individuals like hotel owners, drivers, local bus conductors etc. are often the role models for street-based children or the main sense of connection/stability in their lives. These folks have an impact as constructive and unconstructive role models in the lives of the children and therefore are the protective or risk factors in terms of diverse vulnerabilities on vagrant kids.

Table 3: Vagrant Kids Relationship with Kawaads and Local Community

\begin{tabular}{lcc}
\hline Responses & Number & Percentege \\
\hline Positive & 50 & 50.0 \\
Negative & 44 & 44.0 \\
No idea & 6 & 6.0 \\
Total & 100 & 100 \\
\hline
\end{tabular}

Source: Field Survey, 2013

Majority kids have positive relationships with the Kawaads and community. But, 44\% vagrant kids responded the negative roles of the Kawaads and of the community. They claimed of the negative role played by police who argue the kids are involved in stealing their money, passing urine at the time when the Vagrant kids are sleeping on the streets, hitting the kids by boots, beating, scolding, torturing, using odious words and so forth. The public's perception and attitude towards street children is overpoweringly negative which was experienced during the filed survey and interview sessions with kids. It is deduced from observations and interviews from the kids that vagrant kids are subjected to mental and physical abuse even by their peers and common people. The governments treat them as a scourge that is to be stamp out, rather than as destitute children that need to be nurtured and protected. This is a frightening tendency by some law enforcement personnel and civilians, business proprietors and their private security firms, to analyze street children as almost sub-human. They are frequently detained randomly by police simply because they are homeless, or criminally charged with vague offenses such as loitering, vagrancy, or petty theft. Regarding the negative behavior of community, it is deduced from a lengthy interviews with vagrant kids that the pitiful vagrant kids are often tortured or beaten by police or held for long 
periods in poor conditions without any form of trail or legal process. Girls are sometimes sexually ill-treated. It is construed that few NGOs and activists speak up for these children, and few street children have family members or concerned individuals willing and able to intervene on their behalf. However, in the interview with the police staff by the researchers of this study, it has been lamented by police personnel that vagrant kids' condition seems very pitiable but in reality they are the major problems for the common people as they make noise, quarrel without reasons, use vulgar words, addicted to narcotics, steal and are involved in petty theft.

\subsection{Out of Place: Abandoning Home a Veracity}

The phenomenon of street children is common throughout the country including cities as well as rural areas. The number of children migrating towards the city from rural villages has increased due to the escalating conflict-both external and internal (family). They seek a better future but often end up on the streets in desperate conditions. Some areas in the cities are occupied by slums and because of its vicinity, many of their children move to the street. There are various reasons for the street dwellers behind leaving their home and family away and coming down to the streets.

Table 4: Reasons behind Abandoning Home

\begin{tabular}{lcc}
\hline \multicolumn{1}{c}{ Reasons } & Number of Vagrant kids & Percentage \\
\hline Death of the father & 9 & 9.0 \\
Father has abandoned & 8 & 8.0 \\
Death of Mother & 7 & 7.0 \\
Mother eloped & 8 & 16.0 \\
Misconduct of step parents & 14 & 14.0 \\
Poverty & 13 & 13.0 \\
Lack of love and affection from parents & 20 & 20.0 \\
Having companion with street boys & 13 & 13.0 \\
Attraction towards city life & 8 & 8.0 \\
Total & 100 & 100 \\
\hline
\end{tabular}

Source: Field Survey, 2013

Vagrant kids have multiple reasons to leave home. Majority of kids $(20 \%)$ left the home because of the lack of love and affection from parents-a family problem. Misconduct of step parents (14\%) is another responsible factor behind leaving the home. Some kids left home due to death of father $(9 \%)$, few kids left home ( $8 \%)$ as their father abandoned. Some kids $(7 \%)$ left home due to death of mother. They also left home as their mother eloped. Poverty (13\%) is also one of the major factors compelling the kids to abandon the home. Company with street boys is also a reason behind the kids leaving their homes. The functionalist perspective of regarding family as an institution meeting the societal needs and the disturbances within a family and family malfunctions leading to split in the family consequently preparing the ground for the children to escape from the family seems down-to-earth. Amid the rising trend of urbanization, attraction 
towards city life is also one of the reasons responsible behind the kids abandoning the home and coming to the street and adjusting there. Some of them did not want to reveal their previous addresses. The study clearly shows that the major bulk of the children have migrated from their ancestral rural villages around the country.

In broad-spectrum, most street children come from broken families. Kids reported that they have parents who gave birth to babies but have not taken their responsibilities of taking care of their children seriously. It indicates that children are battered or not provided adequate love, care, and support. Single parents or the presence of a step mother or step father are common phenomena. Children reiterated again and again that if they return to their home there is fear of being beaten by their parents, especially step parents, or the lack of love and care that keeps them away from home. It is deduced from this study that most of the street children are either abandoned by their families or run away from home because of abusive and exploitative family relations. Kids were treated in a sub-human manner.

\section{Kids Frequency of Contact with Family}

This study is based on of the street vagrant kids or the permanent dwellers of streets. Kids left home and permanently dwell on street due to an assortment of raison d'être but some of them are in contact with their family and some are out of contact. It is vital whether Vagrant kids are in contact with their family or not. Do they want to be in contact with their family or not. It is interesting to reveal that, of the street vagrant kids, the majorities interviewed were in contact with family but the frequency of contact is different which is in the figure.

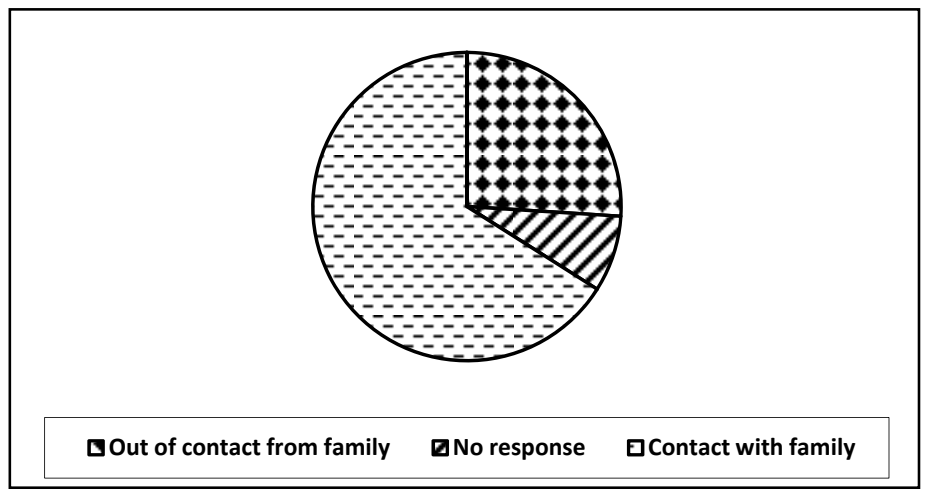

Figure 3: Vagrant Kids Contact to Family

Majority of kids are in contact with their family, $26 \%$ are out of contact from the family. 
Table 5: Frequency of Contact with Family

\begin{tabular}{lcc}
\hline \multicolumn{1}{c}{ Time Duration } & Frequency of Contact & Percent \\
1-7 days & 6 & 6.0 \\
7-30 days & 14 & 14.0 \\
1-6 months & 6 & 6.0 \\
6-12 months & 18 & 18.0 \\
During Festivals & 24 & 24.0 \\
Out of contact/no response & 32 & 32.0 \\
Total & 100 & 100 \\
\hline
\end{tabular}

Source: Field Survey, 2013

About one fourth $(24 \%)$ of the children (18\%) were in contact with family only during festivals, some children are in contact with family in between 6-12 months, 14 percent children are in contact with family in between 7-30 days, and 6 percent children are in contact with family in between duration of few days. Likewise, 32 percent children don't want to be in contact with family. This trend of family contacts despite the permanent settlement of kids on the street reveals that the vagrant kids are emotionally unsecured in street. Hence, they attain emotional support from the contact with the family. Likewise, they want to please their rude and apathetic parents (who otherwise used to beat kids) by helping them with money which they have earned by selling rags.

\section{Sources of Income}

There are various types of work that Vagrant kids get involve in for their earnings. Once the children come to street, they take up all kinds of work. From rag picking to begging, to petty crimes like mugging, vagrant kids are involved in different sorts of activities for survival.

Table 6: Vagrant kids Income Sources

\begin{tabular}{lcc}
\hline Sources of income & Number & Percentage \\
\hline Rag picking & 79 & 79.0 \\
Begging & 19 & 19.0 \\
Selling goods in cinema hall & 1 & 1.0 \\
Construction labour & 1 & 1.0 \\
Total & 100 & 100.0 \\
\hline
\end{tabular}

Source: Field Survey, Pokhara 2013

More than three fourth (79\%) of Vagrant kids depend upon the rag picking work, which is the most popular and widely practiced work. About one fifth (19\%) children earn money by begging in the street and bus. Only one child was found to be working as a minor construction labour to earn money, 1 percent children earn money by selling goods (edible and non-edible) in cinema hall. Rag picking is easy, flexible, and lucrative and children doing this work are basically selfemployed, and are not accountable to anyone. The freedom they enjoy and the money they earn with relative ease attracts many children to do this work. 
Vagrant kids, commonly, work for long hours. Their earnings are directly related to the amounts of items collected (in case of rag picking), which depend on the number of hours they work. On an average they work for about 4-6 hours per day. Daily income of the Vagrant kids varies according to the work and the age group of the children. However, they do not necessarily make money every day. In many cases they remain penniless and hence remain ravenous.

Table 7: Daily Income of Vagrant Kids

\begin{tabular}{lcc}
\hline Income Class (in NRs/day) & Number of Vagrant kids & Percentage \\
\hline Rs. $10-50$ & 2 & 2.0 \\
Rs. $50-100$ & 20 & 20.0 \\
Rs. $100-150$ & 32 & 32.0 \\
Rs. More than 150 & 46 & 46.0 \\
Total & 100 & 100.0 \\
\hline
\end{tabular}

Source: Field Survey, Pokhara 2013

Forty six children earn more than Rs 150 a day, 32 children earn Rs 100-150, 20 children earn Rs 50-100 and only two kids earn only Rs 10-50.

\section{Tribulations Faced By Kids}

Children obviously face various types of tribulations in the streets. Survival, protection, health, legal issues, etc. are the some of the major tribulations they encounter daily. Likewise, abuse and exploitation, social hypocrisy, police harassment, influence of crime, accidents, emotional insecurity, and urban pollution are further tribulations. The reality is that street children do not only fight a single problem but they encounter more than one problem in the same time. Kids face legal problems especially when they are caught in cases of robbery. They also experience problems obtaining legality, identity etc. Economic problems have also been a serious problem street children face. More than 50 percent expressed that they lack money problem on a daily basis. Sometimes, they do not make a single penny in such situation they remain hungry for the time infinite. In broad-spectrum health, security, and social are the problems highly encountered by the street children respectively.

Table 8: Tribulations Vagrant Kids Face in the Street

\begin{tabular}{ll}
\hline \multicolumn{1}{c}{ Problems } & Number of Kids \\
Social problems & 43 \\
Security problems & 52 \\
Health problems & 54 \\
Monetary problems & 50 \\
Legal problems & 50 \\
Other & 13 \\
\hline
\end{tabular}

Source: Field Study, 2013 
Multiple responses of the vagrant kids clarifies that social problem is a major predicament especially the social apathy. Emotional and social problems are experienced by kids. Kansakar (2003) has pointed out that older vagrant street kid lure younger vagrant street kids into sexual activities. The street life is unstructured and destabilizing, nothing is guaranteed, not even the next meal. This unpredictable existence sometimes produces distortions of the mind in the younger children who lose track of time and place. Health is furthermore a big problem street kids' encounter. 54 percent of the interviewed street children face health predicament. The working, living, and eating patterns of these kids create a variety of health problems, most of which are related to unhygienic, overcrowded surroundings and exposure to extreme weather. Sexually Transmitted Diseases (STDs), skin ailments, bacterial and parasitic infections and malnourishment are common among them. They neglect their health due to financial constraints and avoid using the facilities of the government hospitals because they know through experience that they will not be cared for. Lack of health information and education further aggravates these children's problems. Among the most serious threats to the health of street children is their high degree of exposure to drugs and sexual abuse. But the kids are not spending their money on health. Vagrant street kids use cigarettes, alcohol and other drugs. Drugs that are easily available are glue for sniffing, solvents, marijuana etc. These children also have an elevated risk of acquiring STDs and HIV, because of their early revelation to both heterosexual and homosexual activities.

\section{CONCLUSION}

This study has concluded that vagrant kids are bona-fide excluded proto-proletarians of Nepali society transforming and making a status of their own in an innovative but challenging exclusive situation on streets. The study also assure that most Vagrant kids are conscious towards their plight and transforming status in street. Yet, lack of guidance, opportunity, and loss of interest, social apathy and negligence are the factors contributing to the creation of vagrant kids abnormal deviant sub-culture embedded with new underclass class status. The impact of social isolation, stress, and street environment has resulted in negative coping mechanisms among street-based kids manifesting in increased risk-taking behaviors in all activities under which kids are transforming and adjusting to subsist in an exclusive sub-culture of their own with sturdy sense of artificial family (irony) amongst each other where companionship is awfully vital despite recurrent wrangle. This sub-culture (although regarded deviant/abnormal by mainstream) has provided kids with a logic of resistance, affection giving them a sagacity of belonging, a sturdy sense of folks amongst each other and regarding amity as imperative exhibiting a high level of originality and sovereignty at their personal in process of transforming and adjusting to a new harsh and challenging situation in streets with a new identity of being a part of new but risky raucous subculture.

\section{REFERENCES}

ADB (2003). Working with street children - Exploring Ways for ADB Assistance. Manila: Asian Development Bank.

CPCS (2009). Yearly Report. Kathmandu: Author.

CWIN (2008). Situation of Children in Nepal. Kathmandu: Author. 
CWSUK (2011). Study of Policies and Programmes Addressing the Rights of Street Children to Education Nepal. Kathmandu: Child Welfare Scheme Nepal.

Kansakar, K. (2003). Silent Suffering, Child Sexual Abuse in the Kathmandu Valley. Kathmandu: CWIN and Save the Children Norway.

Sharma, P. (2003). Population Monograph of Nepal. Kathmandu: Central Bureau of Statistics.

UNICEF (2010). Annual Report. Retrieved from www.unicef.org/np.

UNICEF (2006). Children and women of Nepal: a situation analysis. Kathmandu: The United Nations Children's Fund.

Upadhyay, P. (2008). Quandary in Nepal: A Conflict Perspective. Himalayan Journal of Sociology and Anthropology, vol. 3, page;

Yeung, Y.M. (1988). A Place of Live, More Effective Low Cost Housing in Asia. Ottawa: IDRC. 